\title{
Development Educational Material Topeng Malang with the Augmented Reality for Supporting Character
}

\author{
Andy Pramono ${ }^{1}$, Wida Rahayuningtyas ${ }^{1}$, Betty Dewi Puspasari ${ }^{2}$, and Adzrool \\ Idzwan Hj. Ismail ${ }^{3}$ \\ ${ }^{1}$ Fakultas Sastra, Universitas Negeri Malang, Malang, Indonesia \\ ${ }^{2}$ STT Atlas Nusantara Malang, Malang, Indonesia \\ ${ }^{3}$ University Utara Malaysia Kedah Malaysia
}

\section{Abstract}

Strengthening the quality of education, especially in the arts and culture, in Indonesia is very important. This can be achieved via the application of technology. Malang is a city that has a lot of traditional cultures, such as masks (Topeng), of which there are about 67 designs. It is a challenge in developing learning materials for Topeng Malang. The influence of the inclusion of modern styles is one of the factors

Corresponding Author:

Andy Pramono

andy.pramoissuefs@um.ac.id

Received: Month 2020

Accepted: Month 2020

Published: Month 2020

Publishing services provided by Knowledge E

(c) Andy Pramono et al. This article is distributed under the terms of the Creative Commons Attribution License, which permits unrestricted use and redistribution provided that the original author and source are credited.

Selection and Peer-review under the responsibility of the ICADECS Conference Committee. stimulating the decline of Malang people's insights related to traditional culture such as Topeng Malang. This research is related to the strengthening of Topeng Malang education media material by using AR technology. This research focuses on insightful content relating to characters in Topeng Malang,especially for supporting models. This research is carried out through descriptive procedural models, which must be followed to produce a development product - data was obtained by interview, data observation, and documentation. Observation data consisted of reference data for the description of supporting character models namely Pranajiwa and Emban, visuals in the form of Topeng Malang, library data and surveys from the target audience.

Keywords: Topeng Malang, Augmented Reality, Support character model

\section{Introduction}

Education in Indonesia has now begun to promote the development of media as a support for education, and this is due to the shifting role of teachers at present as facilitators in the delivery of educational material. The education paradigm, which used to be conventional, is now starting to shift to information technology-based education. These changes include teaching methods, learning references, instructional media and so on (Suprapto, 2012). The use of learning support media helps to learn activities, especially in elementary schools, to secondary schools. With learning support media, 
students can have a more detailed understanding of what is explained by the teacher. Teachers as facilitators are required to be able to prepare teaching media. This learning media can be made with actual equipment or using Information Technology (Syahidi, Supianto, and Tolle, 2019). Mobile-based learning, based on observations at MTSN 1 Malang, found facts in class VII students. Students who have cellphones are 95\% higher. This result is more than computer/laptop ownership by $65 \%$. Types of mobile phones also range from feature phones to smartphones.

Art and culture subject matter: Topeng Malang has a lot of material that needs to explain. Two-dimensional visual content such as symbolic meaning, mask shape, and deformation of mask characters. Another problem is that grade VII students have difficulty understanding material, especially in Topeng Malang art lessons. On the side of the school having problems, the school does not have teaching materials in the form of "unfortunate masks" totaling about 67 types of masks.

The content of Topeng Malang has been taken up by several researchers. Research from Soerjo Wido with the theme of the Symbolic Structure of the Patih Mask Mask Topeng Malang at the Dramatari Show in Kedungmonggo Hamlet, Karangpandan Village, Pakisaji District, Malang Regency, where this research emphasizes the study of symbolic meanings and specific structures. Starch figures about Topeng Malang (Minarto, 2008). Astrini's research in the 2003 RUAS Journal, which examined the semiotic mean of costumes and masks on Topeng Malang (Astrini, Amiuza, and Handajani, 2013). Research by Wida entitled Packaging Material of Topeng Malang Dance Teaching in Malang Vocational Malang in Harmonia journal that examines the description of motion, Topeng Malang dance movements (Rahayuningtyas, 2013).

According to the analysis of research that has been done by another researcher, it can see that there is still a lack of research that examines: a. Character shape from the shape of Topeng Malang, b. Lack of implementation of learning media through mobile technology, c. There are no studies on augmented reality models on the Topeng Malang material.

With the application of ARTop on smartphones, learning methods can be done using drill or practice methods. The training method can apply with Android cellphone-based learning because students can learn more time and can repeat several times (Pramono, 2013). Also, more in-depth understanding of the material Topeng Malang. Through the development of learning media, Topeng Malang to answer the problem and increase knowledge of the material Topeng Malang using mobile technology. ARTop is an offline learning media application based on Android phones. ARTop develope so that students quickly learn bad masks, minimizing costs in learning. 


\section{Literature Review}

Studies of articles that have been carried out related to Topeng Malang and augmented reality have been carried out by several researchers who can learn in the following explanation: The dancer symbol is the center of life. Klana Sewandana is a relationship with villages related to culture. The symbols of behavior in life implied in the Topeng Malang. The article in the journal with the title "Local Wisdom through Learning Topeng Malang Dance" by Dewayani in 2017, the finding of this study through learning dance can simultaneously provide moral values that students need to have basic foundation for students to continue their education to a higher level (Dewayani, 2017). Articles in international journals titled "The Symbolic Meaning of the Role of Wayang Topeng in Malang, East Java, Indonesia" by Robby Hidajat. The findings of this study internalized by the community in the village of Kedungmonggo are a symbol of the role of wayang Topeng related to the environment. Panji Asmoro Wake is a relationship with the entity "Pundhen" (Hidajat, 2005). Provide conceptual contributions to moral values in learning dance. Augmented Reality is one technology that offers a new way to educate. Due to the increasing use of mobile devices globally, the widespread use of AR on mobile devices such as smartphones and tablets has become a growing phenomenon (Nincarean, Alia, Halim, and Rahman, 2013). There is research related to the use of augmented reality in articles: current status, opportunities, and challenges of augmented reality in education in the journal Computers and Education (Hsin-Kai, Silvia Wen, Hsin-Yi, and Jyh-Chong, 2013). There are studies related to the use of augmented reality in education namely articles: Augmented and virtual reality applications in industrial systems: A qualitative review towards the industry 4.0 era in the journal IFAC-PapersOnLine (Damiani, Demartini, Guizzi, Revetria, and Tonell, 2018)

\section{Research Problems}

From the research of Topeng Malang, it can see that there is still a lack of research that examines the use of technology, especially cellphones in poor mask visualization in general and the absence of research that applies augmented reality models to visualize Topeng Malang. Noting this can be drawn into the issue of how to develop media as an educational support media as the application of technology in the learning of Topeng Malang to improve the quality of education in Indonesia. 


\section{Research Model}

Research on the theme of art education and humanities, the sub-theme of developing a tick-based digital learning model that encourages autonomy for learning is done by improving the theory of Borg WR and Gall MD, to produce certain stages as below.

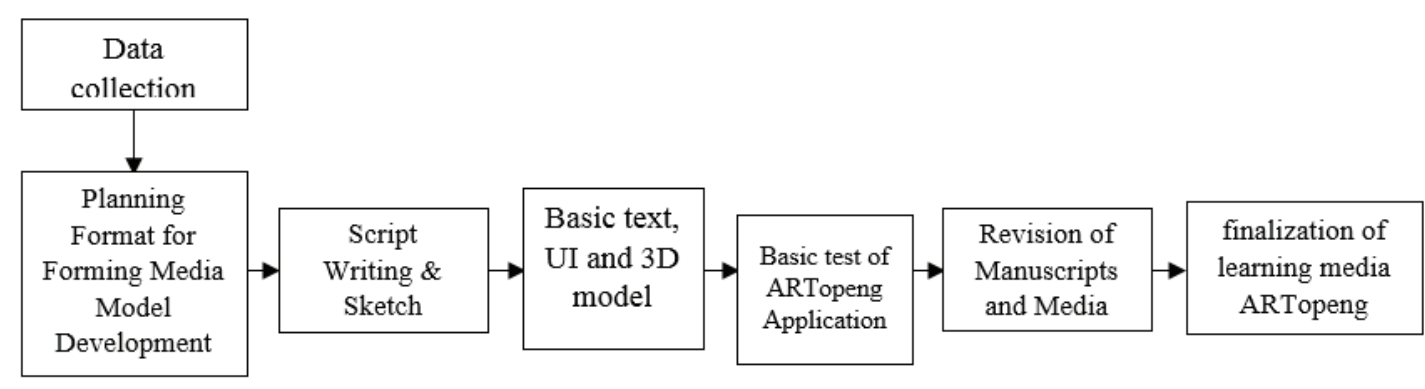

Figure 1: Research Model (Borg and Gall, 2003)

Data collection is the first step in carrying out this development research. At this stage, literature review activities are carried out, data collection, and needs analysis related to information about the learning conditions of the Topeng Malang in Malang city junior high school. Literature review activities include the following actions: (a) analyzing the contents of the curriculum in arts and culture subjects and skills, in order to find concepts, functions, goals, and scope; competency standards, essential competencies, and substance of Topeng Malang learning materials; (b) Data collection is done using observation, interview, and document techniques. The use of these three data collection techniques is intended to capture as much data as possible to obtain various findings during the research: (c) analyze the concepts and material substance for the development of augmented reality learning media technology on Android.

Format Planning Phase to Establish Media Model Development: the phase of planning applications, filling out forms and model selection. Writing and Script Sketching Phase:

The step of preparing the contents script and model sketches which are the results of evaluating the Topeng Malang form. Phase Basic text, UI, and 3D models: the phase of conducting typographic analysis, layout design, and making three-dimensional models based on the results at the sketch stage. Basic Test Phase for ARTopeng Application: the phase of converting the three-dimensional model format, and the implementation of the model placement in the application. In the content writing section, and implementation of the design has made. The phase of Revision of Manuscripts and Media: The step of evaluating the test results and making improvements. The level of finalizing ARTopeng learning media: stage combining mask module, mask character design module and character explanation module. 


\section{Results and Discussion}

In collecting data, it known that the Topeng Malang used in the performance of the Topeng Malang dance is not all can presented in the story. It depends on the story presented in the performance of the Topeng Malang dance. From Malang Mask data, as shown in Figure 2, we can see the shape of the eyes, eyebrows, nose, mouth, mask color, and hat shape. The results of the data collection and analysis stages of Malang Mask arranged as an example in table 1

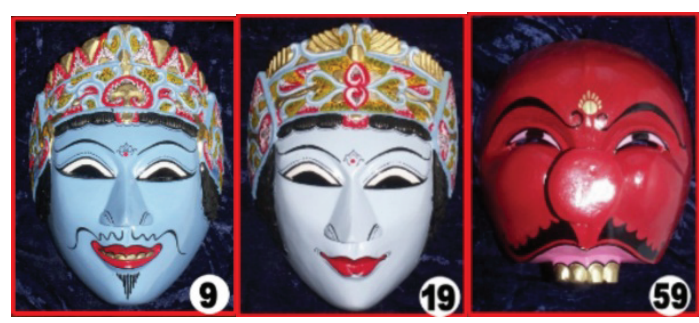

Figure 2: Topeng Malang data

TABLE 1: example identification of Topeng Malang Character

Character Name

Characteristics of Masks
- Eye: Penanggalan
- Nose: Gandik'an
- eyebrow: Kluwung
- mouth: Nyopet
- Eye: Penanggalan
- Nose: Gantik'an
- eyebrow: Kluwung
- mouth: Nyopet

Character and Role in
Psychological Dimensions
Protagonist Nature: cheerful, loyal,
loyal

In the next stage a three-dimensional topeng malang design is carried out. The making of three-dimensional objects with shapes, colors and textures is made as closely as possible with topeng malang data. The results can be seen in Figure 3 .

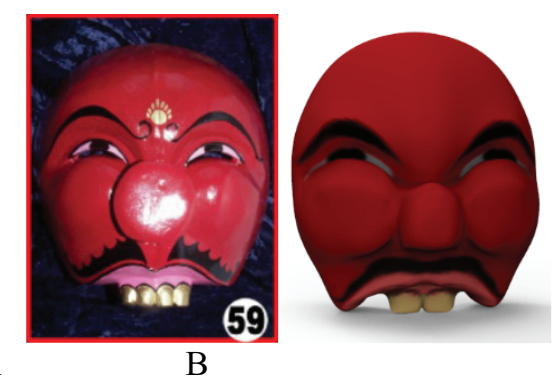

Figure 3: A. Topeng Malang Data, B Model 3 Dimensi Topeng Malang

At the design stage, the three-dimensional character Topeng Malang. The first step from the results of table 1 and reference data, sketches the characters. The coloring 
and texture of the characters doing through the Adobe Photoshop application. As can be seen in the example in Figure 3

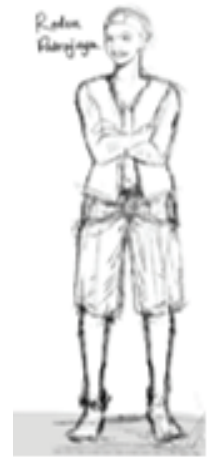

a

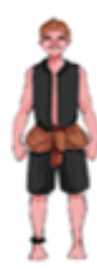

Figu

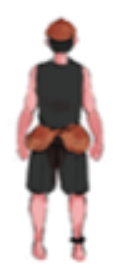

8

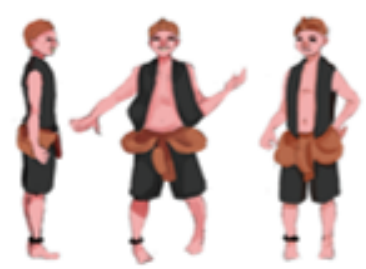

$\mathrm{b}$

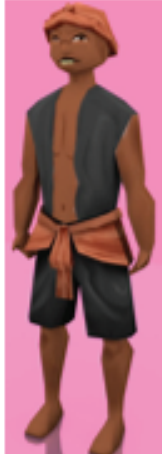

c

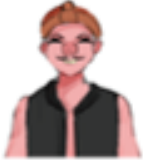

Figure 4

The design phase of the augmented reality application uses the scenario reference in Figure 4. First, the first test is conducted using 1 character, namely Pranajaya mask. The project is carried out for 2 types of 3-dimensional models and 1 type of image format jpg. This Pranajaya character for 3 types uses 1 marker. The initial test results for Malang Pranajaya masks see in Figure 5.

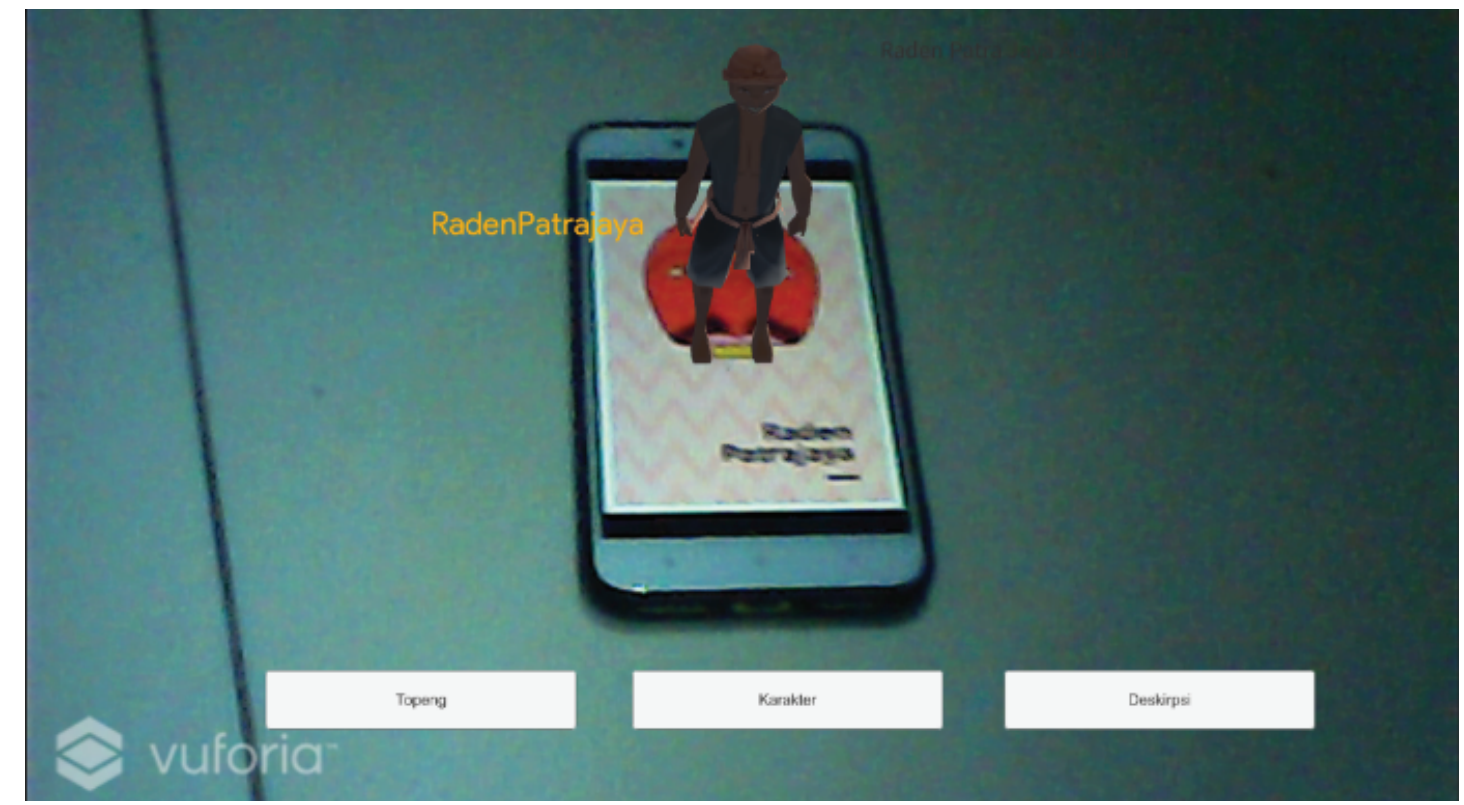

Figure 5: Pranajaya Trial for marker and 3D model 


\section{Trial and Error}

In this study produced a visualization and simulation applications ARTopeng based on android that can visually display the user to obtain the 3D model designs for all markers. Application results of this research at an early stage have the APK file extensions with large $80,2 \mathrm{Mb}$, at this early stage then made some improvements on the display interface by changing some of the description views using image format then after correction is obtained at the final stage of the application form format APK with large file $78,6 \mathrm{Mb}$. Based on the results of trials that have conducted on 8 gadgets in the laboratory of Art and Design Department Universitas Negeri Malang Indonesia, is obtained as in Table 2.

TABLE 2: Results of Trial Application

\begin{tabular}{|c|c|c|c|c|c|c|c|}
\hline & Instalasi & Registrasi & Model & Warna & Desain & Simulasi & Visualisasi \\
\hline Lenovo A369i & Ok & Ok & Ok & Ok & Int Ok Eks Ok & Ok & Ok \\
\hline Lenovo S820 & Ok & Ok & Ok & Ok & Int Ok Eks Ok & Ok & Ok \\
\hline Samsung Galaxy Chat & Ok & err & err & err & err & err & err \\
\hline Samsung S2 & Ok & Ok & Ok & Ok & Int Ok Eks Ok & Ok & Ok \\
\hline Samsung Galaxy W & Ok & Ok & Ok & Ok & Int Ok Eks Ok & Ok & Ok \\
\hline Lenovo S880 & Ok & Ok & Ok & Ok & Int Ok Eks Ok & Ok & Ok \\
\hline
\end{tabular}

\section{Conclusion}

Based on the results for research on the application of ARTopeng visualization, application design: Topeng Malang based on Android can be said to run well at the stage of analysis, concept, implementation until the initial test phase. With a success rate of $83 \%$ when testing with 8 Gadgets. The application on students results in an average score of $89 \%$ of students experiencing an increased understanding of the material Topeng Malang.

\section{References}

[1] Astrini, W., Amiuza, C. B., and Handajani, R. P. (2013). Semiotika Rupa Topeng Malangan (Studi Kasus: Dusun Kedungmonggo, Kec. Pakisaji, Kabupaten Malang). Jurnal RUAS, vol. 11, issue 2, pp. 89-98.

[2] Gall, M. D., Borg, W. R., \& Gall, J. P. (2003). Educational research: An introduction (7th ed.). Longman Publishing. https://www.pearson.com/us/higher-education/product/ Gall-Educational-Research-An-Introduction-7th-Edition/9780321081896.html 
[3] McCormick, B. H., DeFanti, T. A. and Brown, M. D. (1987). Visualization in Scientific Computing. ACM SIGGRAPH Computer Graphics, vol. 21, issue 6, pp. 15-21

[4] Carmigniani, J., et al. (2011). Augmented reality technologies, systems and applications. Multimedia Tools and Applications, vol. 51, issue 1, pp 341-377.

[5] Cooper, A., Reimann, R., Cronin, D., \& Cooper, A. (2007). About face 3: The essentials of interaction design. Indianapolis, IN: Wiley Pub.

[6] Damiani, L., et al. (2018). Augmented and virtual reality applications in industrial systems: A qualitative review towards the industry 4.0 era. IFAC-PapersOnLine, vol. 51, issue 11, pp. 624-630. https://doi.org/10.1016/j.ifacol.2018.08.388

[7] Dewayani, W. (2017). Kearifan Lokal Melalui Pembelajaran Tari Topeng Malang Untuk Menumbuhkan Karakter Siswa Sekolah Menengah Kejuruan Negeri 5 Malang Jawa Timur. Jadecs, vol. 2, issue 1, pp. 26-35.

[8] Owen, G. S., Domik, G., Rhyne, T. M., Brodlie, K. W., \& Santos, B. S. (1999). Hypervisteaching scientific visualization using hypermedia. Georgia State University., ACM SIGGRAPH Education Committee, the National Science Foundation, and the Hypermedia and Visualization Laboratory.

[9] Hariyanto, G., (2011). Definisi Visualisasi, Animasi dan Simulasi, August 1, 2020 from http://guruh-al-horford-fst08.web.unair.ac.id/

[10] Hidajat, R. (2005). Struktur, Simbol, Dan Makna Wayang Topeng Malang. Jurnal BS, vol. 2. Issue 1, pp. 270-281.

[11] Hoekman Jr, R. (2010). Designing the moment: Web interface design concepts in action. Peachpit Press.

[12] Hsin-Kai, W., Silvia Wen, Y., Hsin-Yi, C., and Jyh-Chong, L. (2013). Current status, opportunities and challenges of augmented reality in education. Computers and Education, vol. 62, pp. 41-49. https://doi.org/10.1016/j.compedu.2012.10.024

[13] Lee, K. (2012). Augmented Reality in Education and Training. TechTrends, vol. 56, issue 2, pp 13-21. https://doi.org/10.1007/s11528-012-0559-3

[14] Minarto, S. W. (2008). Struktur Simbolik Tari Topeng Patih Pada Pertunjukan Dramatari Wayang Topeng Malang Di Dusun Kedungmonggo Desa Karangpandan Kecamatan Pakisaji Kabupaten Malang (Doctoral dissertation, Universitas Negeri Semarang).

[15] Müller, N. M., and Tina, S. (2018). "Effects of Self-Regulation Prompts in Hypermedia Learning on Learning Performance and Self-Efficacy,." Learning and Instruction, vol. 58, pp. 1-11. https://doi.org/10.1016/j.learninstruc.2018.04.011.

[16] Nincarean, D., alia, M. B., Halim, N. D. A., and Rahman, M. H. A. (2013). Mobile augmented reality: The potential for education. 13th International Educational 
Technology Conference, vol. 103, pp. 657-664. https://doi.org/10.1016/j.sbspro.2013. 10.385

[17] Pramono, A. (2017). Media Pendukung Pembelajaran Rumah Adat Indonesia Menggunakan Augmented Reality. Jurnal Eltek, 11(1), 122-132.

[18] Rahayuningtyas, W. (2013). Pengemasan Bahan Ajar Tari Topeng Malang Pada Mata Kuliah Vokasi Tari Malang. Journal Harmonia: Journal of Arts Research and Education, vol. 13, issue 1, PP. 29-36. Diambil dari https://journal.unnes.ac.id/nju/ index.php/harmonia/article/view/2530

[19] Setiawan, S. (1991). Teknik Pemrograman, Yogyakarta: ANDI.

[20] Suprapto. (2012). Peningkatan Kualitas Pendidikan Melalui Media Pembelajaran Menggunakan Teknologi Informasi di Sekolah. Jurnal Ekonomi dan Pendidikan, vol. 3, issue 1. PP. 34-41. https://doi.org/10.21831/jep.v3i1.632

[21] Sutopo, A. H. (2002). Analisis dan Desain Berorientasi Objek. Yogyakarta: J and J Learning.

[22] Syahidi, A. A., Supianto, A. A., and Tolle, H. (2019). Design and Implementation of Bekantan Educational Game (BEG) as a Banjar Language Learning Media. International Journal of Interactive Mobile Technologies (iJIM), vol. 13, issue 3, pp. 108-129.

[23] Tay, V. (2004). Multimedia : Making It Work Edisi 6. Yogyakarta: ANDI. 